TEME, г. XLIII, бр. 4, октобар - децембар 2019, стр. 981-996

Прегледни рад

https://doi.org/10.22190/TEME191011058J

Примљено: 11. 10. 2019.

UDK 504:628.4:352(497.11)

Ревидирана верзија: 18. 10. 2019.

Одобрено за штампу: 1. 12. 2019.

\title{
SECURITY THREATS AND CHALLENGES - INADEQUATE WASTE MANAGEMENT AT THE LOCAL LEVEL IN THE REPUBLIC OF SERBIA
}

\author{
Đorđe Jovanović ${ }^{\prime *}$, Tatjana Živković ${ }^{2}$ \\ ${ }^{1}$ Union Nikola Tesla University, School of Engineering Management, \\ Belgrade, Serbia \\ ${ }^{2}$ Belgrade City Administration, Belgrade, Serbia \\ jovdjor@gmail.com
}

\begin{abstract}
Inadequate management of waste originating from industry and other activities, communal and service actions, health protection, agriculture and natural person's activities, creates threats and security challenges at the local level within the Republic of Serbia (RS). In this paper, the author systemically analyzes and assess all these problems regarding the diverse generation of waste putting it in the context of public authorities' jurisdiction on all levels, as well as in the context of waste generators. It is specifically assessed in the context of strategic planning documents, laws and bylaws, historical pollution (temporarily stored waste), unsuitable (criminal) waste disposal in locations that are not designed for such purposes, as well as security challenges and threats in that sense. A landfill as a complex has a direct impact on the environment and its mediums, which is especially analyzed in this paper, as well as its impact on human health and the quality of life. Moreover, through an analysis of these impacts and threats (by stating concrete examples for these statements) in the Republic of Serbia, the manners for potential reduction of all these challenges and threats in the local environment are analyzed and discussed with the help of various contemporary approaches and models already applied world-wide, and the recommendations for their use are provided.
\end{abstract}

Key words: $\quad$ waste, security, local level, environment, the Republic of Serbia.

\section{БЕЗБЕДНОСНИ ИЗАЗОВИ И ПРЕТЬЕ - НЕАДЕКВАТНО УПРАВЉАЊЕ ОТПАДОМ НА ЛОКАЛНОМ НИВОУ У РЕПУБЛИЦИ СРБИЈИ}

\footnotetext{
Апстракт

Неадекватно управљање отпадом који је пореклом из различитих привредних и других активности, комуналних и услужних делатности, здравствене заштите, пољопривреде и активности физичких лица - ствара претње и безбедносне изазове на локалном нивоу у Републици Србији (РС). У раду се системски анализирају и
} 
сагледавају сви ови проблеми у вези са генерисањем отпада различитог порекла стављајући то у контекст надлежности државних органа на свим нивоима, као и генератора отпада. Посебно се наведено сагледава и у контексту стратешкопланских докумената, закона и подзаконских аката, историјског загађења (привремено ускладиштеног отпада) и неодговарајућег (криминалног) одлагања отпада на локације које за то нису предвиђене и безбедносне изазове и претње у том смислу. Депонија као објекат има непосредан утицај на животну средину и њене делове (медијуме), што се у раду посебно анализира, као и утицај на људско здравље и квалитет живота. Такође, у раду се кроз анализу ових утицаја и претњи (навођењем конкретних примера за ове тврдње) у РС, анализирају и дискутују начини за потенцијално смањење свих ових изазова и претњи у локалном окружењу (животној средини), помоћу различитих савремених приступа и модела који се примењују у свету и дају препоруке за њихову примену.

Кључне речи: отпад, безбедност, локални ниво, животна средина, Република Србија.

\section{INTRODUCTION}

In the widest sense, waste occurs as a ,negative product” and a consequence of any economic activity performed with a goal of creating a product or providing services. It indispensably occurs at the end of the useful life span of any product. The waste (of any kind and origin, dangerous, etc.) is generated in the place of origin. Adequate management of waste and its disposal often occurs as a regional and sometimes even national state problem. Integral waste management implies the implementation of a series of prescribed measures and activities of conduct (the collection, transport, storage, treatment, disposal, monitoring and the maintenance of facilities for waste management after their closure) (SEPA, Otpad i upravljanje otpadom, N.D).

Problems in the field of waste management, regardless of whether they occur on the global or regional level, always have a local determinant (Petrović, 2012, 531), that is, they manifest on a local level (Vavić, Živković and Jovanović, 2009, 188). The condition present among us is that inadequate waste management is one of the biggest and most complex problems in regards to the environment (Vavić, Jovanović and Živković, 2009, 64). Ecological delicts (Jovašević, 2014, 627) in the field of waste management in the Republic of Serbia, besides being a matter of the Criminal Law (Joldžić and Jovašević, 2012, 58), have not been sanctioned in a proper manner and within the right measure yet.

The democratization of society has led to the issues regarding the environment (Jovanović L., Jovanović Đ., 2014) and the quality of life being highly ranked on the list of values of the contemporary society, on the collective level, but the individual as well (Jovanović, Joldžić and Jovanović, 2015). The rights of citizens regarding the issues of the environment are contained within the Aarhus Convention as an international contract ratified even by the Republic of Serbia, and in 2009, a form of law was adopted in Serbia modelled on this international contract (Aarhus Convention) (Official 
Gazette of the Republic of Serbia-International Contracts, 2009), with complementary Strategies for its implementation (Official Gazette of the Republic of Serbia, 2011).

In developed countries, the concept of ,green and circular economy" (Ghisellini, Cialani and Ulgiati, 2016, 16) has been implemented for a long time, and it has found its use in different industries (Lieder and Rashid, 2016, 42). Such an approach implies the maximum use of generated waste in all the phases of the product's life span, as well as the reduction of the quantity of the deposited waste and all the risks and threats that might appear as a consequence. It must be acknowledged that the state in this field in the Republic of Serbia is still far from the mentioned standard, since the biggest part of the produced waste is deposited, and only a small amount of it recycled. The state of undeveloped mechanisms pertaining to waste production and disposal results in the contribution to the increase of various forms of risks and threats on a local level.

\section{THE METHODOLOGICAL BASIS OF THE CONDUCTED RESEARCH}

The methods used in this research are analysis and content analysis. The author used publicly-available data and SEPA Reports, as well as data available from other foreign and domestic sources. The fundamental question is: to what point is the current state connected to the lack of systemic order, and which part is linked to the lack of implementation of the existent laws and strategies? To that end, the author conducted an analysis of legal and strategic planning documents in the field of waste and waste management in the Republic of Serbia. The security challenges and threats occurring due to inadequate waste management on the local level, in regards to landfills as complexes, municipal waste, industrial waste and other types of waste are in this paper identified and analyzed. In this way, the current state is reviewed and possible ways for reducing challenges and threats in regard to waste management on the local level are suggested.

\section{THE ANALYSIS OF LEGAL AND STRATEGIC PLANNING DOCUMENTS IN THE FIELD OF WASTE MANAGEMENT}

Waste management is a complex task that demands suitable organization capacities of all bodies, from the highest state authorities to the local self-government, as well as the cooperation between various interested parties. Planning waste management is regulated by the legal obligation of passing and adopting planning documents by different subjects participating in this field of work. (Živković, 2019, 350). Sectoral, material regulation that deals with the field of waste management and conduct is the Law on Waste Management, and the Strategy for Waste Management and its implementation falls under the obligations of the line ministry. Passing 
Table 1. Laws directly or indirectly connected to the field of waste management and the analysis of the fulfillment of the said obligations by the competent authorities

\begin{tabular}{|c|c|}
\hline Law title & Obligations of the competent authorities \\
\hline $\begin{array}{l}\text { Law on Protection of the } \\
\text { Environment } \\
\text { The Official Gazette of the Republic } \\
\text { of Serbia, no. } 135 / 2004,36 / 2009 \text {, } \\
36 / 2009 \text { - state law, } 72 / 2009 \text { - state } \\
\text { law, } 43 / 2011 \text { - decision of the } \\
\text { Constitutional Court, } 14 / 2016 \text {, } \\
76 / 2018,95 / 2018 \text { - state law and } \\
95 / 2018 \text { - state law }\end{array}$ & $\begin{array}{l}\text { Ministry for the protection of the environment } \\
\text { - did not fulfill its legal obligations (Art. } 5 \text {. } \\
\text { Par. 1. and Art. } 30 \text { of the Law). Provincial } \\
\text { Authorities - did not fulfill their legal } \\
\text { obligations (Art. 5. Par. } 1 \text { and Art. } 30 \text { of the } \\
\text { Law). Local self-governments - did not fulfill } \\
\text { their legal obligations (Art. } 5 \text { Par. } 1 \text { and Art } 30 \\
\text { of the Law). }\end{array}$ \\
\hline $\begin{array}{l}\text { Law on Waste Management } \\
\text { The Official Gazette of the Republic } \\
\text { of Serbia, no. 36/2009, 88/2010, } \\
14 / 2016 \text { and } 95 / 2018\end{array}$ & $\begin{array}{l}\text { Ministry for the protection of the environment } \\
\text { - did not fulfill its legal obligations (Art. } 18 \\
\text { and } 84 \text { of the Law). Provincial Authorities - } \\
\text { did not fulfill their legal obligations (Art. } 19 \\
\text { and } 84 \text { of the Law). Local self-governments - } \\
\text { did not fulfill their legal obligations (Art. } 20 \\
\text { and } 84 \text { of the Law). }\end{array}$ \\
\hline $\begin{array}{l}\text { Law on Packaging and Packaging } \\
\text { Waste } \\
\text { The Official Gazette of the Republic } \\
\text { of Serbia, no. 36/2009 and 95/2019 } \\
\text { and the state law }\end{array}$ & $\begin{array}{l}\text { Ministry for the protection of the environment } \\
\text { - did not fulfill its legal obligations (Art. } 47 \text { of } \\
\text { the Law). Provincial Authorities - did not } \\
\text { fulfill their legal obligations (Art. } 47 \text { of the } \\
\text { Law) }\end{array}$ \\
\hline $\begin{array}{l}\text { Low on Local Self-Government } \\
\text { The Official Gazette of the Republic } \\
\text { of Serbia, no. } 129 / 2007,83 / 2014- \\
\text { state law, } 101 / 2016 \text { - state law and } \\
47 / 2018\end{array}$ & $\begin{array}{l}\text { Local self-governments - did not fulfill their } \\
\text { legal obligations (Art. } 20 \text { Par. 1. P. } 8 \text { of the } \\
\text { Law) }\end{array}$ \\
\hline
\end{tabular}

Law on Communal Activities Local self-governments - did not fulfill their The Official Gazette of the Republic legal obligations (Art. 3. Par. 1. P. 4. of the of Serbia, no. 88/2011, 104/2016 and Law). 95/2018

$\begin{array}{ll}\begin{array}{l}\text { Law on Privatization } \\ \text { The Official Gazette of the Republic } \\ \text { of Serbia, no. 83/2014, 43/2015, } \\ 112 / 2015,20 / 2016 \text { - authentic } \\ \text { interpretation }\end{array} & \begin{array}{l}\text { Ministry responsible for business affairs - did } \\ \text { Law). }\end{array} \\ \begin{array}{l}\text { Law on Public-Private } \\ \text { Partnership (PPP) and } \\ \text { Concessions }\end{array} & \begin{array}{l}\text { Within the Law on PPP, there is not a clearly } \\ \text { defined jurisdiction regarding the supervision } \\ \text { of application of the concluded contracts. }\end{array} \\ \begin{array}{l}\text { The Official Gazette of the Republic } \\ \text { of Serbia, no. 88/2011, 15/2016 and } \\ 104 / 2016\end{array} & \begin{array}{l}\text { Neither the Board for PPP nor any other body } \\ \text { has jurisdiction or is obliged to collect data on } \\ \text { contract application and the conduct of public } \\ \text { partners. The Law does not contain penal } \\ \text { provisions, which is one of its major } \\ \text { deficiencies. }\end{array} \\ & \end{array}$


regional and local plans for waste management is a legal obligation in the Republic of Serbia. The Law on Waste Management stipulates that the local self-government Assembly should pass a local plan for waste management for the given territory. Adopting a regional plan for waste management, as a legal obligation, falls within the jurisdiction of the assemblies of two or three local self-government units, or the autonomous province (Živković, Vavić and Jovanović, 2009, 72). The regional plan for waste management (for more than 220.000 habitants) includes data collection with regards to: existent utility companies, landfills on the territories of the municipalities included in the said plan, quantities of waste and its content, prices for waste collection and disposal, percentage of territory coverage of the said region by waste collectors, etc.

Table 2. The Analysis of the expiry-date of the strategic planning documents in the field of waste management in the Republic of Serbia

\begin{tabular}{|c|c|}
\hline Document title & Expiry-date \\
\hline $\begin{array}{l}\text { National Strategy for Waste Management for the } \\
\text { period } 2010 \text { - 2019. The Official Gazette of the } \\
\text { Republic of Serbia, no. } 88 / 2010\end{array}$ & $\begin{array}{l}10 \text { years, expired in } \\
\text { April } 2019\end{array}$ \\
\hline $\begin{array}{l}\text { National Program for the Protection of the } \\
\text { Environment. The Official Gazette of the Republic of } \\
\text { Serbia, no. } 12 / 2010\end{array}$ & $\begin{array}{l}10 \text { years, expired in } \\
\text { January } 2019\end{array}$ \\
\hline $\begin{array}{l}\text { National Strategy for Sustainable Development } \\
\text { (The Official Gazette of the Republic of Serbia, no. } \\
57 / 2008 \text { ) }\end{array}$ & $\begin{array}{l}10 \text { years, expired in June } \\
2018\end{array}$ \\
\hline $\begin{array}{l}\text { National Environmental Approximation Strategy. The } \\
\text { Official Gazette of the Republic of Serbia, no. 80/2011 }\end{array}$ & $\begin{array}{l}\text { Regarding the field of } \\
\text { waste management, } \\
\text { expired in January } 2019\end{array}$ \\
\hline $\begin{array}{l}\text { Strategy for Introduction of Cleaner Production in the } \\
\text { Republic of Serbia. The Official Gazette of the } \\
\text { Republic of Serbia, no. } 17 / 2009\end{array}$ & $\begin{array}{l}10 \text { years, expired in } \\
\text { March } 2019\end{array}$ \\
\hline $\begin{array}{l}\text { Spatial Plan of the Republic of Serbia. The Official } \\
\text { Gazette of the Republic of Serbia, no. } 88 / 2010\end{array}$ & 10 years, expires in 2020 \\
\hline
\end{tabular}

Through analyzing the legislative-legal context of the fulfilment of demands in the field of environment protection (for state authorities within the Republic of Serbia on all levels), it might be said that a significant number of the said demands are not fulfilled or are partially fulfilled, and usually not implemented systematically or at all. By conducting an analysis of the expiry-date of the strategic planning documents regarding the field of waste management in the Republic of Serbia, it can be seen that they have most often expired, and that the activities planned by these documents usually remain unfulfilled due to various reasons (organization, financing, etc.). 
The analysis of criminal acts against the environment within the Criminal Law (which was not separately listed in Table 1) leads towards the conclusion that inadequate waste management is not defined as a criminal act (consequential pollution of the environment), thus leaving a wide space for illegal management of waste of different origin.

Based on the available data (SEPA, Otpad i upravljanje otpadom, N.D.) (SEPA, Katastar deponija, N.D.), it can be concluded that, out of 28 regions, 13 of them do not even have the waste management plan adopted. Out of 148 existent local self-governments, 24 of them did not draft a plan. Having in mind that the Strategy for Waste Management has just expired (consequentially, as the majority of the before mentioned plans did too), local self-governments do not have the legal basis for making the said plans in the future until the new Strategy for Waste Management is adopted (and it has not yet been passed).

The before mentioned is a clear indicator of the contempt of the law passed by the state (ministries), the Autonomous Province of Vojvodina, a certain number of local self-governments, and it is also an indicator of the catastrophic strategic planning inconsistency in the field of waste management on all levels in the Republic of Serbia. This points to the lack of any plan for the future in this field in Serbia, any real financing for the obligations and activities previously provided by adopted, and now expired, plans. For all the before mentioned stances, no sanctions stipulated by legal regulations were introduced.

\section{THE ANALYSIS OF SECURITY CHALLENGES AND THREATS DUE TO INADEQUATE MUNICIPAL WASTE MANAGEMENT}

Through an analysis of municipal waste management at the local level in the Republic of Serbia, it might be said that the current state in Serbian municipalities is characterized by unreliable and incomplete data on the quantity and quality of generating municipal and household waste. Further analysis refers to the inadequacy of landfills in the context of the fulfillment of legal provisions referring to this field and security challenges and threats in this sense.

Waste disposal in the Republic of Serbia is regulated by the Decree on landfilling of waste (Official Gazette of the Republic of Serbia, 2010) which stipulates (Article 1.):

"The conditions and criteria for determining the location, technical and technological project conditions, construction and landfill operation, types of waste forbidden from being landfilled, the amount of biodegradable waste that can be landfilled, criteria and procedures for accepting or not accepting, that is, disposing the waste in the landfill, the manner and procedures for operating and closing a landfill, content and monitoring of the landfill operation, as well as additional maintenance of the landfill after being closed." 
Furthermore, the "Rulebook on methodology for designing recovery and remediation projects" (Official Gazette of the Republic of Serbia, 2015) stipulates the methodology for designing recovery and remediation projects, as well as recovery and remediation of the present unsanitary landfills of municipal waste - dumps. Great non-uniformity of the existent dumps demands for a definition of methodology for four groups of possible unsanitary landfills - dumps that will: ultimately be closed; be used up to three years; be used for five or more years, and the ones that directly endanger water sources (no matter the size and service life).

Based on the data acquired from Public Communal Companies, the Serbian Environment Protection Agency (SEPA) conducted an analysis for the purpose of preparing the Report on the State of the Environment. The analysis of the collected data was conducted based on the „Landfill Cadaster", created by SEPA (SEPA, Katastar deponija, N.D.). After analyzing the said report, it might be said that within the territory of the Republic of Serbia, there are 164 landfills used by Public Communal Companies for waste disposal. The land on which the landfills are located is (most often) the property of the state or the local self-government, that is, the property of a certain company. The age of a single landfill ranges from 5 new ones (Bačka Palanka - Obrovac, Bela Palanka, Malo Crniće, Pančevo and Tutin) to the oldest one dating from 1956 (Silbaš, Bela Palanka municipality).

The data on the dimensions and volume of the landfill body is usually not the most reliable. The recorded volumes are usually overestimated, since for a majority of them there is no (suitable) technical documentation. The biggest landfills in the Republic of Serbia are located in the biggest cities (Beograd, Nišs, Novi Sad), and the majority of the analyzed data from the local municipalities have mechanization and vehicles for collecting waste from specialized roto press skid loaders and skid steers for large containers, to simple trucks and tractors equipped with trailers. The lack of suitable equipment for waste collection is visible and significant, as it is the case with the mechanisms used for landfill manipulations. Covering waste (with the goal of manifold risk reduction) is conducted on 117 landfills, that is, on $72 \%$ of them, and they are in most cases covered by earth or some other inert material. On 15 landfill location, the covering is being conducted on a daily basis, and on 101 of them in accordance with the needs (SEPA, Katastar deponija, N.D.).

Analyzing data on the distance of landfills from water bodies also paints a devastating picture. Up to 25 landfills (15.2\%) are located at the distance of less than $50 \mathrm{~m}$ from the local river, stream or lake side or some water accumulation, and 14 landfills are practically located on the water side or in its hull (SEPA, Katastar deponija, N.D.). A total of 32 (20\%) municipalities did not present any data on this. A total of $11(6.7 \%)$ landfills are located at a distance of less than $500 \mathrm{~m}$ from the water supply zone, and $28(12.2 \%)$ are located at a distance of less than $1000 \mathrm{~m}$ from the said zone 
(SEPA, Katastar deponija, N.D.). It might be expected with great certainty that the landfill body might be connected to the watercourses in the location of the landfill and the geological characteristics of the soil. Only 63 municipalities reported data on the distance of landfills from the protected natural goods and monuments of the significance for the cultural heritage. Landfills in three municipalities are situated less than $100 \mathrm{~m}$ from the said objects, and in eight municipalities, they are located less than $1000 \mathrm{~m}$ from them (SEPA, Katastar deponija, N.D.).

Table 3. The number of landfills interacting in some way with watercourses (SEPA, Katastar deponija, N.D.)

\begin{tabular}{lc}
\hline Type of landfill and watercourse interaction & Number of landfills \\
\hline Watercourse is registered within the landfill body & 12 \\
Watercourse is registered in the proximity of a landfill & 65 \\
There is a possibility of an interaction between the & 46 \\
landfill and the watercourse & 28 \\
The landfill is in or near the floodplain & \\
\hline
\end{tabular}

By analyzing data on the distance of landfills from settlements, it might be concluded that they are alarming too, given that, from the total number of landfills, 12 of them (7.3\%) are located less than $100 \mathrm{~m}$ from settlements Katastar deponija, N.D.), which speaks of the endangerment of the population from the landfill pollution, but also of possible occurrence of various illnesses passed by animals living on landfills.

\section{ANALYSIS OF SECURITY CHALLENGES AND THREATS DUE TO INADEQUATE MANAGEMENT OF OTHER TYPES OF WASTE}

When analyzing the security challenges and threats in the context of industrial waste at the local level, it might be said that (dangerous) industrial waste management is one of the biggest ecological, health and security issues in the Republic of Serbia. There are significant amounts of toxic and cancerogenic (dangerous) waste originating from private but also abandoned industrial facilities as historical pollution (waste, etc.). The operation of a facility generates additional new quantities of waste that are often inadequately and illegally resolved (by burial). This has, unfortunately, lead to ecological incidents on numerous locations, and thus has seriously endangered the population's health and the ecological security on the territory of the Republic of Serbia.

Every subject of waste management is obliged to respect the legal praxis of depositing, transporting and removing (dangerous) waste. In practice, there are many more examples of inadequate waste management. But regardless of whether it is the case of depositing dangerous waste in the proximity of an inactive factory, that is, a bankrupt or abandoned building, or 
the case of an unconscientious operator or producer that, besides illegally depositing the waste also conducts illegal transport and removal of dangerous waste, the fact is that the responsible authorities are not taking measures stipulated by the law. The most common examples of such security challenges are the following: „Viskoza” in Loznica (leakage of hazardous substance from the 350 cubic meter reservoir into the Drina River, with the risk of further spillage into the Sava River in 2014), as well as nine abandoned factories around which a great amount of dangerous waste is piled (white liquor, green liquor, rare black liquor, sodium hydroxide, sulfuric acid, formaldehyde, butyl acetate, ethyl alcohol, etc.).

In the non-privatized factories of „Zorka” Company in Šabac, which have not been operative for years, the chemicals stored in completely destroyed plants, tanks and pipelines, located in the immediate vicinity of the Sava coast, pose the potential danger and threat to human health and the environment. We are speaking of about 5,500 tons of concentrated sulfuric acid stored in above ground tanks.

During 2018, on the fields near the coast of the Sava River in the vicinity of Obrenovac, buried barrels of about 110 tons of hazardous waste were repeatedly found; in May 2018, within the premises of „Beo tok” (slaughterhouse industry) from Pančevo, hydrochloric acid waste (about 10 tons) was poured directly from the tanks into the city rain sewer; ,Eko 21 ” operator from Pančevo, registered for pickup, temporary storage and export of hazardous waste, according to the statement of the inspection in 2018, improperly treats and stores hazardous waste (improper facilities and infrastructure - manipulating plateau, septic tank, access road and other).

Significant contribution to raising awareness and informing the public about and prioritizing this issue goes to electronic and written media, which publicly give increasing importance to these topics (Jovanović and Aćimović, 2014, 338). Thus, this thematic content and its media presence influence the creation of a better and different environment and an attitude towards values in the context of the environment, health and quality of life (Jovanović and Aćimović, 2014, 340) in our country (Jovanović, Bajac, Radović, Matavulj and Antonović, 2013, 88).

In 2019, the authorities (SEPA) have filed criminal and misdemeanor charges under the laws governing the field of environmental protection. These reports were filed to the National Pollutant Source Register against companies that did not submit data (or have provided incorrect data) on products that, after use, become separate waste streams.

In 2018, a total of 1961 misdemeanor charges were initiated against companies that did not submit any data on products placed on the market in the Republic of Serbia, and a total of 357 criminal charges were initiated in 2016, 2017 and 2018 targeting companies that provided incorrect data when entering data into the information system. Based on the information available to SEPA, obtained from the Customs Administration, the estimated fee for incorrectly entered data is about 4.8 billion dinars in total. 
In May 2019, all the companies that have not fulfilled the obligation of submitting the annual report were sent a notification regarding the disregard for their obligations (a total of 4797 companies), after which the majority of the said companies corrected this omission (SEPA, August 21, 2019).

The disposal of treated (and untreated) medical waste at landfills (or dumps) can (indirectly) pose a risk for pathogenic and toxic pollutants found in the environment. Out of the total amount of generated waste in the medical sector, about $85 \%$ amounts to non-dangerous and $15 \%$ to dangerous waste, which is often infectious, toxic or radioactive. Annually, about 16 billion injections are used world-wide, but not all of them are properly disposed after use.

The uncontrolled combustion of the said waste at landfills can result in the emission of dioxins, furans and particulates (WHO, 2018), which poses an ecological and health challenge and a threat on a local level. What the state needs to do to achieve a universal solution in the long run is an urgent action that should be taken at the local level.

The example of this threat are illegal landfills in the Republic of Serbia on which fires occur due to self-inflammation (of generated landfill gases) or the intention of extracting secondary resources from the waste. The „Vinča” landfill burned for several days, even despitethe Belgrade fire department interventions in 2018.

In mid-2019, a serious problem of landslide present on the landfill body was remedied. Namely, the city of Belgrade, as the signatory of the Contract on PPP (providing services of treatment and disposal of municipality waste and „Vinča” landfill remediation with a private partner, a French-Japanese corporation), fulfilled the contractual obligation in the preparatory phase of the realization of the contract in question by remediating the landslide.

\section{COMMENT}

Inadequate waste management (now is not being defined as a criminal act), might broadly be classified as the criminal act of „Environmental Pollution“ or „Failure to take Environmental Measures“. However, by analyzing available data in the sense of the insignificant number of filed criminal charges and initiated and implemented proceedings for the said offenses, the following might be concluded. Legally defined broad legal terms (,,pollution on a larger scale or in a wide area") are problematic for public prosecutors for evaluation, and thus, within the process of evidence presentation, not even the expert findings (without on-site investigations), can not be competent to initiate and conduct criminal proceedings. Thus, criminal sanctions for inadequate waste management, in the context of the said criminal acts, can be proven only in rare cases, and are thus negliglible, in the form of an insignificant fine. 
The penalty policy is the only solution to the criminal disposal (burial) of hazardous waste of different origin on a private property. There have been numerous talks on this topic in the press, electronic media, and the ministry is urging citizens to report such cases on its website (Ministry of Environmental Protection, n.d.). By the end of 2018, the proposals for amendments to the Criminal Code and for a new crime called "eco-terrorism" emerged. The term "eco-terrorism" began to be talked about and written about at the end of the last century (Schwartz, D.M. 1998), and the pro-ecologically motivated criminal activity in recent decades has been expanding (Matković, 2013, 531). In the context of waste management, the term "eco-terrorism" is linked to illegal and unconscious dangerous waste disposal (most often by burial, discharge into rivers, etc.). This act represents a criminal activity against human health and the environment.

In recent times, there has been significant development and implementation of the concept of PPP in the Republic of Serbia in the field of utilities and waste management (Brdarević and Jovanović, 2012, 107). In this sense, local self-governments might be able to start planning and projecting improved systems for waste recycling, waste minimization and waste management. On the state level, the conditions and criteria for the creation and implementation of legal regulations (including financing, control and penalty policy), as well as strategies and plans for waste management, should be more clearly defined.

\section{CONCLUSION}

Inadequate waste management on the local level poses numerous threats and security challenges with consequently numerous other environmental and human health implications. In the Republic of Serbia, waste management is practically based on local landfills (dumps) waste disposal, that (with a few exceptions) do not fulfil even the basic hygienic and technical-technological conditions. Besides that, some existing disposal sites are practically almost full. In accordance with the existent state, in Serbia, only a few landfills might be seen as sanitary landfills. As a consequence, an inadequate recycling level is also present.

Public utility companies in the field of waste management are founded and should (almost) exclusively deal with municipality waste. However, due to the fact that this system is unregulated in the Republic of Serbia, all other categories of waste of different origin, including dangerous waste, end up on the landfills that are planned for the storage of municipality waste. One part of dangerous industrial waste is not deposited in landfills anymore, but neither is it exported for treatment (even though it might seem that way) - it is illegally deposited in the surrounding (by burial) without authorization, as stated in this paper. Therefore, it turns to be a serious criminal act against security of people and the environment on a local, but also wider, regional and state level. 
On the territory of the Republic of Serbia, urgent systemic improvement of municipality waste management through establishment of organized and separate collection, sorting and waste recycling is necessary. Waste management demands for constant investment and accompanying costs, with the goal of avoiding potential security challenges and threats on the local level. On the other hand, inadequate waste management leads towards an increase of expenses of environment pollution, health expenses and the impact on population health in the state. This consequentially impacts the health protection system and health funds. This has a direct and negative impact on part of the environment and the food production through the inability to produce healthy food on the territory of the Republic of Serbia.

Environmental allocations at the current level are insufficient and must be increased several times, in line with the strategies in this area. The overall result of this situation are the security challenges and threats on the local level, arising as the result of inadequate management of waste of different origins.

ACKNOWLEDGEMENTS. The authors gratefully acknowledge the support from the Project of Matica srpska entitled „Environment and the perspectives of quality development and health safety of food in AP Vojvodina".

\section{REFERENCES}

Brdarević, Lj., Jovanović, Đ. (2012). Razvoj i primena koncepta javno-privatnog partnerstva u Republici Srbiji, Kvalitet i izvrsnost, 1(1/2), 106-109. [Development and implementation of the concept of public-private partnership in the Republic of Serbia, Quality and Excellence, 1(1/2), 106-109.]

Ghisellini, P., Cialani, C., and Ulgiati, S. (2016). A review on circular economy: The expected transition to a balanced interplay of environmental and economic systems. Journal of Cleaner Production, 114, 11-32. doi.org/10.1016/j.jclepro. 2015.09.007

Joldžić, V., Jovašević, D. (2012). Ekološko krivično pravo, [Environmental criminal law] Institut za kriminološka i sociološka istraživanja, Beograd.

Jovanović, L., Jovanović, Đ. (2014). Strategijski značaj i primena Arhuske konvencije u Republici Srbiji, [Strategic Significance and the Implementation of the Aarhus Convention in the Republic of Serbia], Monograph, Naučno-stručno društvo Ecologica.

Jovanović, Đ., Aćimović D. (2014). Medijska zastupljenost tema iz oblasti zaštite životne sredine, [Media Representation of Topics in the Field of Environmental Protection] Ecologica, 74, 204-211.

Jovanović, Đ., Aćimović, D. (2014). Pitanja životne sredine i dostignuti stepen medijske pokrivenosti u Republici Srbiji, [The Issues of the Environment and the Achieved Level of Media Coverage in the Republic of Serbia], Tehnika, vol. 69(2), 332-342. doi:10.5937/tehnika1402332J

Jovanović, Đ., Bajac, M., Radović, D., Matavulj, M., i Antonović, D. (2013). Attitude towards the environment in the context of the strategic development of system of values in Serbia, Ecologica, 20(71), 75-380. 
Jovanović, L., Joldžić, V., Jovanović Đ. (2015). Arhuska konvencija i demokratizacija u oblasti životne sredine, [The Aarhus Convention and Democratization in the Field of Environmental Protection], Monograph, Naučno-stručno društtvo Ecologica.

Jovašević, D. (2014). Sistem ekoloških delikata u Srbiji, [System of environmental delicts in Serbia], Teme, XXXVIII (2), 621-639.

Кривични законик. Службени гласник РС, бр. 85, 88 и 107 (2005), бр. 72 и 11 (2009), бр. 121 (2012), бр. 104 (2013), бр. 108 (2014) и бр. 94 (2016). [Criminal Law, Official Gazette of the Republic of Serbia, no. 85, 88 and 107(2005), no.72 and 11 (2009), no.121 (2012), no. 104(2013), no. 108(2014) and no. 94(2016).]

Lieder, M., and Rashid, A. (2016). Towards circular economy implementation: A comprehensive review in context of manufacturing industry. Journal of Cleaner Production, 115, 36-51. doi.org/10.1007/s00170-017-0610-9

Matković, A. (2013). Proekološki kriminal, [Proecological kriminal], Pravni zapisi, 4(2), pp. 529-546.

Ministry of Environmental Protection of the Republic of Serbia. (n.d.) Retrieved from: https://www.ekologija.gov.rs/; Acessed: 21. 8. 2019.

Ministry of Protection of Natural Resources and the Environment of the Republic of Serbia. (2003). Uticaji privatizacije na životnu sredinu - lekcije za zemlje u razvoju. [Environmental Impacts of Privatization - Lessons for Developing Countries] Beograd, no. 426; World Bank Report Translation.

Национална Стратегија за апроксимацију у области животне средине. Службени гласник PC, бр. 80 (2011). [National Strategy for Approximation in the field of Environment Protection. Official Gazette of the Republic of Serbia, no. 80 (2011).]

Национални програм заштите животне средине. Службени гласник PC, бр. 12 (2010). [National Program for the Protection of the Environment. Official Gazette of the Republic of Serbia, no. 12 (2010).]

Petrović, M. (2012). Zaštita životne sredine na lokalnom nivou: percepcija ključnih aktera, [Ecology at the local level: the perception of the key subjects], Teme, XXXVI (2), 525-544.

Правилник о методологији за израду пројеката санације и ремедијације. Службени гласник PC, бр. 7 (2015). [Rulebook on methodology for designing recovery and remediation projects. Official Gazette of the Republic of Serbia, no. 7 (2015).]

Правилник о методологији за прикупљање података о саставу и количинама комуналног отпада на територији јединице локалне самоуправе. Службени гласник PC, бр. 61 (2010). [Rulebook on methodology for collecting data on the composition and quantities of municipal waste in the territory of the local selfgovernment unit. Official Gazette of the Republic of Serbia, no. 61 (2010).]

Просторни план Републике Србије. Службени гласник PC, бр. 88 (2010). [Spatial plan of the Republic of Serbia. Official Gazette of the Republic of Serbia, no. 88 (2010).]

Republican Public Prosecutor's Office. (n.d.). Retrieved from: http://www.rjt.gov.rs; Acessed: 21. 8. 2019

Schwartz, D.M. (1998). Environmental Terrorism: Analyzing the Concept. Journal of Peace Research, 35(4), 483-496. doi.org/10.1177/0022343398035004005

SEPA. (N.D.). Otpad i upravljanje otpadom. Retrieved from: http://www.sepa.gov.rs/ index.php?menu=207\&id=202\&akcija=showXlinked; Acessed: 21. 8. 2019

SEPA. (N.D.). Katastar deponija. Retrieved from: http://www.sepa.gov.rs/index.php? menu=9\&id=6003\&akcija=showAll\#a3; Acessed: 21.08 .2019

Стратегија о управљају отпадом 2010-2019. Службени гласник РС, бр. 88 (2010). [Strategy for Waste Management 2010-2019. Official Gazette of the Republic of Serbia, no. 88 (2010).] 
Стратегија увођења чистије производње у Републици Србији. Службени гласник PC, бp. 17 (2009). [Strategy for the introduction of cleaner production in the Republic of Serbia. Official Gazette of the Republic of Serbia, no. 17 (2009).]

Стратегија за примену Конвенције о доступности информација, учешћу у јавности у доношењу одлука и праву на правну заштиту у питањима животне средине Архус конвенција. Службени гласник РС, бр. 103 (2011). [Strategy for the implementation of the Convention on Access to Information, Public Participation in Decision-Making and the Right to Legal Protection in Environmental Matters Aarhus Convention. Official Gazette of the Republic of Serbia, no. 103 (2011)]

Уредба о одлагању отпада на депоније. Службени гласник PC, бр. 92 (2010).[Decree on Waste Disposals on Landfills. Official Gazette of the Republic of Serbia, no. 92 (2010).]

Vavić, I., Živković, T., and Jovanović, Đ. (2009). Nastanak otpada kao posledica industrijskog akcidenta, Zbornik radova Industrijski otpad, (187-196) Druga međunarodno-stručna konferencija o upravljanju otpadom, [Waste generation as a result of an industrial accident, Second International Expert Conference on Waste Management] Tara: Forum kvaliteta

Vavić, I., Jovanović, Đ., i Živković, T. (2009). Upravljanje industrijskim otpadom u cilju prevencije nastanka akcidenta, [Industrial waste management in order to prevent accidents], Kvalitet, 19 (9/10), 63-66.

World Health Organization. (2018). Health-care waste. Retrieved from: https://www.who. $\mathrm{int/news-room/fact-sheets/detail/health-care-waste;} \mathrm{Acessed:} \mathrm{21.8.2019}$

Закон о амбалажи и амбалажном отпаду. Службени гласник РС, бр. 36 (2009) и бр. 95 (2018). [Law on Packaging and Packaging Waste. Official Gazette of the Republic of Serbia no. 36 (2009) and no. 95 (2018)]

Закон о комуналним делатностима. Службени гласник РC, бр. 88 (2011), бр. 104 (2016) и бр. 95 (2018). [Law on Utility Actions. Official Gazette of the Republic of Serbia, no. 88 (2011), no. 104 (2016) and no. 95 (2018)]

Закон о јавно приватном партнерству и концесијама. Службени гласник РС, бр. 88 (2011), бр. 15 (2016) и бр. 104 (2016). [Law on PPP and Concessions. Official Gazette of the Republic of Serbia, no. 88 (2011), no. 15 (2016) and no. 104 (2016)]

Закон о локалној самоуправи. Службени гласник РС, бр. 129 (2007), бр. 83 (2014 др. закон), бр. 101 (2016 - др. закон) и бр. 47 (2018) [Law on Local SelfGovernment. Official Gazette of the Republic of Serbia no. 129(2007), no. 83(2014 - state law), no. 101(2016 - state law) and no. 47(2018)]

Закон о потврђивању Архуске конвенције. Службени гласник РС - Међународни уговори, бр. 38 (2009). [ Law on Confirmation of the Aarhus Convention. Official Gazette of the Republic of Serbia - International Contracts, no. 38 (2009)]

Закон о приватизацији. Службени гласник РС, бр. 83 (2014), бр. 43 и бр. 112 (2015), бp. 20 (2016). [Law on Privatization. Official Gazette of the Republic of Serbia, no. 83 (2014), no.43 and no. 112 (2015), no. 20 (2016)]

Закон о управљању отпадом. Службени гласник РС, бр. 36 (2009), бр. 88 (2010), бр. 14 (2016) и бр. 95 (2018) [Law on Waste Management. Official Gazette of the Republic of Serbia, no. 36 (2009), no. 88 (2010), no. 14 (2016) and no. 95 (2018)]

Živković, T. (2013). Primena kaznenog prava prema zakonu o zaštiti životne sredine, [Application of criminal law under environmental law] Strani pravni život, 1, 321-332.

Živković, T. (2014). Inspekcijski nadzor u oblasti zaštite životne sredine, [Inspection control in the field of environmental protection], Monografija, Zadužbina Andrejević.

Živković, T. (2019). On the efects of the dispersion of the implementation of the waste managment strategy in the Rebublic of Serbia, Science, education, technology and 
inovation SETI I, Internacional Scientific Conference, Belgrade, 2019, (1), pp. 347-355.

Živković, T., Jovanović, Đ. (2014). Usaglašenost zakonodavstva u oblasti životne sredine u Republici Srbiji sa preporukom evropske unije o inspekcijskom nadzoru, [Compliance of environmental legislation in the Republic of Serbia with the European Union recommendation on inspection], Strani pravni život, 1, 279-292.

Živković, T., Vavić, I., and Jovanović, Đ. (2012). Nadležnost organa lokalne samouprave u oblasti zaštite životne sredine - primer grada Beograda, Kvalitet $i$ izvrsnost, [The jurisdiction of the local authorities in the field of environmental protection - the case of the City of Belgrade, Quality and Excellence], 2 (1/2), $96-99$.

Živković, T., Vavić, I., and Jovanović, Đ. (2012). Zaštita životne sredine i nadležnost organa lokalne samouprave, Zbornik radova Forum kvaliteta CHYMICUS IV, o pravno-ekonomskim i ekološkim aspektima sistema upravljanja zaštite životne sredine u hemijskoj, petrohemijskoj $i$ naftnoj industriji, IV međunarodni kongres, [Environmental Protection and Competence of Local Self-Government Bodies, Proceedings of the CHYMICUS IV Quality Forum, on Legal, Economic and Ecological Aspects of the Environmental Management System in the Chemical, Petrochemical and Petroleum Industries, IV International Congress], Tara, 59-64.

\title{
БЕЗБЕДНОСНИ ИЗАЗОВИ И ПРЕТЬЕ - НЕАДЕКВАТНО УПРАВЉАЊЕ ОТПАДОМ НА ЛОКАЛНОМ НИВОУ У РЕПУБЛИЦИ СРБИЈИ
}

\author{
Ђорђе Јовановић $^{1}$, Татјана Живковић ${ }^{2}$ \\ ${ }^{1}$ Универзитет Унион Никола Тесла, Факултет за инжењерки менаџмент, Београд, \\ Србија \\ ${ }^{2}$ Градска управа града Београда, Београд, Србија
}

\section{Резиме}

Неадекватно управљање отпадом на локалном нивоу изазива бројне претње и безбедносне изазове, са последично бројним другим импликацијама везаним за животну средину и људско здравље, што представља један од највећих нерешених системских проблема у РС. У раду се анализирају и сагледавају проблеми у вези са стварањем отпада различитог порекла и решавањем отпада (депоновања), стављајући то у контекст надлежности државних органа на свим нивоима, као и генератора отпада. Наведено се посебно сагледава у контексту стратешко-планских докумената, закона и подзаконских аката, историјског загађења (привремено ускладиштеног отпада), неодговарајућег (криминалног) одлагања отпада на локације које за то нису предвиђене и растућој појави безбедносних изазова и претњи у том смислу. У РС је практично једини начин управљања отпадом одлагање на локалне депоније (сметлишта), које (са веома мало изузетака) не задовољавају ни основне хигијенске и техничко-технолошке услове. Поред тога, нека од постојећих одлагалишта су практично сасвим попуњена. Према постојећем стању, у РС је врло мали број депонија које се могу сврстати у санитарне депоније. Последично томе, присутан је и неадекватан степен рециклаже.

Када је у питању управљање отпадом и његово депоновање, мора се нагласити да депонија, као објекат, има одређени и непосредан утицај на животну средину и њене појединачне делове (медијуме). Овај утицај (услед неадекватног управљања 
отпадом) повећава се и посебно анализира у раду као претња људском здрављу и, последично, смањењу квалитета живота на локалном нивоу. Кроз анализу утицаја и претњи (навођењем конкретних примера за ове тврдње) у РС, анализирају се и дискутују начини за потенцијално смањење свих ових утицаја у локалном окружењу (животној средини), помоћу различитих савремених приступа и модела који се примењују у свету и дају препоруке за њихову примену.

Анализирајући законодавно-правни контекст испуњености захтева у области животне средине (за државне органе у РС на свим нивоима), може се рећи да један значајан број ових захтева није испуњен или је испуњен само делимично, најчешће само на папиру. Анализирајући рокове важности стратешко-планских докумената везаних за област отпада у РС, уочава се да су они углавном истекли, да су активности које су овим документима планиране углавном остале неиспуњене из различитих разлога (организација, финансирање и др.).

У РС је зато потребно хитно системско побољшање управљања комуналним отпадом (али и свим другим врстама отпада), кроз успостављање организованог и одвојеног сакупљања, сортирања и рециклаже отпада. Управљање отпадом подразумева стална улагања и пратеће трошкове у циљу избегавања потенцијалних безбедносних изазова и претњи на локалном нивоу. Са друге стране, због неадекватног управљања отпадом, имамо и повећане трошкове загађења животне средине, лечења и утицаја на људско здравље, што у РС последично утиче на целокупни систем здравствене заштите и здравствене фондове. Значајна негативна и системска последица је утицај на пољопривредну производњу, кроз потенцијалну немогућност производње здравствено безбедне хране на територији РС, о чему посебно морамо водити рачуна у будућности. 